\title{
A genuinely free press?
}

Journalists need look again at the conventions and practices which conceal their reliance on information subsidies from their audiences. A genuinely free and open press can only exist where readers can recognise where the hand of government has helped in writing the news they read and watch.

\section{By IAN WARD}

Error of opinion may be tolerated where reason is left free to combat it.

- Thomas Jefferson, 4 March 1801.

RULE ONE in the "How to Conduct a Coup d'etat Handbook" may be to seize control of all news media. A free press is not something that authoritarian regimes hold dear. However, those of us who prefer parliamentary and democratic political systems see the importance of a free and open media, and indeed, the importance of defending this principle.

The essential argument for a free press is straightforward enough. In a democratic political system voters must choose between those who would govern them. In order to choose wisely they need be well informed. In order to make a genuine choice at the ballot box voters must be able to freely discuss the alternatives amongst themselves. Hence democracy will be diminished where the news media are prevented from publishing information, or from providing a forum for the public consideration of issues.

However, if the importance of the principle of a free press is self evident, the principle itself is elusive. Moreover ways to best defend it are not immediately obvious. It is worth recalling that the very first calls for press freedom made no appeal to the importance of democracy.

John Milton's Areopagiticia (1644) challenged government licensing and censorship by arguing that God gave individuals the capacity to reason, to 
choose between right and wrong. Hence censorship was contrary to God's plan because it stifled the opportunity for individuals to read, to consider, exercise discretion and opt for a Christian life. Of course Milton wrote in an era when kings still claimed to rule by divine right. His tract serves to remind that the principle of press freedom has its roots in liberal attempts to limit the power of the state, and not indemocratic thinking.

The idea of "press freedom" has an old fashioned ring to it. The broadcast media - television in particular - are the dominant news media in most societies. Moreover this is the age of the Internet and of global media empires. The ways we have of publishing information and debating ideas are rapidly changing. We need re-think ways of articulating and defending press freedom.

The problem is not simply that the cry "television freedom" does not have the same resonance as "press freedom", that the call for a free Internet lacks the symbolic force of the call for a free press. Rather the problem is the liberal baggage which the concept of press freedom still carries. The cornerstone of liberalism is belief that the state - that is government - is the chief enemy of freedom. Press freedom was originally understood as something to be won from governments. As John Keane writes in Democracy and the Media (1991) that "Liberty of the press" has often been thought of "as an epic, heroic fight of the individual against political power" vested in the state and understood in terms of the freedom of individuals or groups to express themselves without the constraint of government censorship. (Keane's complaint is that in this "heroic struggle" against unwarranted government control, mass media have been wrongly "viewed as a passive or neutral conduit through which information about the world circulates". I will return to this point.)

\section{Freedom of Information}

The idea that press freedom must be won from governments is bound up in the rationale for Freedom of Information legislation. In a nutshell FOI legislation aims to empower citizens against their political masters by entrenching their right to information held in government files.

In 1993, Raymond Snoddy, then a Financial Times correspondent, wrote a book about the British Press entitled The Good, the Bad and the Unacceptable. In it he argued that

The single most effective way to extend press freedom .... would be to pass a Freedom of Information Act. Such an act would declare all official 


\section{IAN WARD}

information to be in the public domain with narrowly specified exceptions. Such rights to freedom of information were first introduced in Scandinavia, in the Swedish Constitution of 1776, spread to the USA in 1966, and are now part of the legislative framework in Commonwealth countries such as Australia, New Zealand and Canada.

The logic of Snoddy's argument is impeccable. Governments have increasingly been drawn into regulating and making policy in areas which touch the lives of citizens in a great many ways. Journalists can only properly carry out their role of informing citizens "on everything from transport safety and the environment to health and the quality of the products we buy" if they have unfettered access to the information that governments use to make the policy decisions which affect our lives.

I understand that in Fiji legislation proposing to establish Freedom of Information is being currently debated. Similar legislation was introduced in Australia by the Commonwealth government in 1982 (and thereafter by the various Australian states). In essence the 1982 Australian FOI legislation established three basic rights:

$\square$ An individual right to inspect and correct personal records created and held by government departments and agencies.

$\square$ A general right to access documents held by government agencies.

$\square$ A general right to information about the organisation of government and its decision-making processes requiring agencies to publish this information.

Snoddy writes that the introduction of FOI legislation in Australia produced "positive results". But did it?

Critics have seen FOI as "freedom from information". Their point is that FOI legislation invariably exempts a great many government documents (having to do with security, trade, commercial confidence and of course "cabinet confidentiality". As well Australia's federal Freedom of Information Act restricts the right of access to laws no older than December 1977. It also imposes a $\$ 30$ search fee for documents, obliges journalists seeking information to pay the costs of searching out information requested, and thus imposes a considerable cost on general "fishing expeditions" where the specific document sought is not known. There is also a time cost: under the federal FOI Act agencies have 30 calendar days in which to respond to requests.

Learning to use FOI effectively has - Channel Nine's FOI Guide website declares - become a necessity "in these days of investigative journalism" . In 
A GENUINELY FREE PRESS?

her book Reviving the Fourth Estate, Julianne Schultz observes that "one of the chief tools of American investigative joumalists is access to official documents". She notes that until the introduction of FOI, Westminster conventions of secrecy surrounding Cabinet and the public service prevented journalists from accessing even innocuous official documents and records.

Following the introduction of FOI legislation at the state and federal level, Schultz says

The Age and Canberra Times led the way in recognising the potential of FOI for access to hitherto confidential government and information and devoted staff, time and money to developing expertise in its use.

Nine's FOI Guide is much more sanguine. It notes that "Australian journalists rarely get big scoops from FOI requests" and suggests that most journalists use FOI in unimaginative ways. My assessment is that FOI legislation did not transform Australian journalists into diligent watchdogs of the public interest.

\section{Government-Media relations}

Why did the introduction of FOI legislation not expand the capacity of Australian media to scrutinise government and hold it accountable? The answer lies in understanding the routine interaction between news media and government.

When I was preparing this address I happened upon an advertisement in The Australian newspaper. The job entailed, among other things, providing "an Internent news service and a regular radio news service to rural stations". "Experience in radio news", the ad said, "is highly desirable". Applicants were sought with (among other things) "an ability to seek out stories". They would be qualified if they had completed a journalism cadetship or if they held a degree with a major in journalism. The position on offer was not with a cutting edge radio broadcaster, nor even in a newsroom. It was in the "Public Relations Section" of the Department of Agriculture, Fisheries, and Forestry. This ad points to an important fact. Governments hire journalists. Journalists working for governments routinely engage in writing the news.

In his recent study of how spin doctors manipulate the news, The Invisible Persuaders, David Michie suggests that in Britain 80 per cent of business news and 40 per cent of general news "has been directly influenced by PR". This lesson has not been lost on governments. Governments everywhere have 


\section{IAN WARD}

learned the art of "packaging the news", of steering journalists towards covering the news stories they want and in the form they want. Having departments hire journalists to produce ready-made interviews with ministers and other senior officials which radio news rooms can then access by phone (or even via the Internet) is just one of the methods which the federal Australian government will use.

The $\mathrm{BBC}$ has recently carried stories of politicians bribing Thai journalists to give them favourable news coverage. Australian politicians are far more subtle. Ministers are served by teams of press secretaries, and the government by its media unit, the Government Members Secretariat. The government has a co-ordinated media strategy and is perfectly willing to contract PR consultants to deal with particular problems. Individual ministers have learned how to selectively leak information and to "put journalists on the drip". News coverage is systematically monitored so that the most effective strategies of news management can be identified. Open press conferences are now rare. Truncated, staged-for-television-doorstop inteviews are the norm. As a result, the day-today reporting of Australian politics draws heavily upon "information subsidies" provided by the government.

Similar forms of media manipulation are practised in the US, Britain, Canada, and elsewhere. Julianne Schultz argues that "sophisticated news management [has] fundamentally changed the relationship" between the news media and government. It attempts to transform news media into an adjunct of government - helping the government of the day garner public support, generally acting as its publicity branch. If she is right we cannot - in Keane's words - view news media as neutral conduits through which information circulates. It also follows that freedom of the press cannot be secured by FOI legislation or other measures limiting the capacity of government to withhold information. For liberty of the press is ultimately embedded in journalistic practice. A free press, Schultz argues, requires not neutral but "activist" reporters prepared to enage in a "watchdog style of journalism" and to subject the powerful to close and constant scrutiny. She points to investigative journalism as the clearest example of this.

\section{Investigative journalism}

Investigative journalism has its origins in the USA where the introduction of FOI appears to have given it a particular impetus. It is a resource intensive form of journalism. It involves freeing teams of journalists from the daily routines of 116 PACIFIC JOURNALISM REVIEW 6:1 2000 
Can investigative journalism secure or enrich a free media? The answer is no. Investigative journalism does not deal with everyday reporting of politics. It has no answer to the routine practice of news management by government. newswork to pursue a long-term investigation-typically of corruption or political waste an inefficiency. It takes a certain courage on the part of editors because there can be no guarantee that an investigation will generate any news stories at all. Julianne Schultz argues that in Australia "over the decade of the 1980 s ... journalists produced an impressive body of investigative reporting". This is true. In my own state of Queensland the ABC Four Corners "Moonlight State" programme exposed wide-spread police corruption and triggered the Fitzgerald Inquiry and - in turn - a host of substantive reforms in public administration.

Can investigative journalism secure or entrench a free media? The answer is no. Investigative journalism does not deal with the mundane, with the everyday reporting of politics. It has no answer to the routine practice of news management by government.

Moreover it requires the investment of considerable resources in an environment of ing of news rooms.

\section{Public Journalism}

Debate among journalists in the USA where politicians have perfected and practised news management techniques has more recently followed a different trajectory. In the 1980s some journalists - disillusioned by the extent and success of media manipulation practised by candidates on the 1984 and then 1988 presidential campaign trail - turned to "disdaining the news". This meant writing about the role of spin doctors, exposing the ways in which campaign events were staged for television, and conducting "reality checks" on campaign promises and election ads. This strategy for disempowering spin doctors failed. Indeed when television news determined to hold political "spots" up to the scrutiny of a reality check, spin doctors immediately saw the opportunity to reach a prime time audience and prepared ads expressly designed to win this 


\section{IAN WARD}

news media, attention! In the wake of disdaining the news, some journalists determined to find other way of reporting federal elections other than by following candidates from one stage-managed media event to the next. The result was public (or civic) journalism.

Its proponents see public journalism as providing people with the news and information they need to function as citizens. As Edward Fouhy wrote in a 1996 essay he entitled "Civic Journalism: Rebuilding the Foundations of Democracy", journalists in this tradition will "broaden their agenda from the usual overwhelming focus on political and governmental news to aggressively feret out issues of interest to citizens who are not members of the elite". Public journalism will cover "an agenda that is set more by citizens, by the people, and less by those who would manipulate them".

The goal of public journalism is to strengthen the civic culture, to reconnect people to their communities, to rebuild citizenship and draw people into politics and civic affairs.

Its leading proponent, Jay Rosen argues in Getting the Connections Right (1996) that public journalism

calls on the press to help revive civic live and improve public dialogue and to fashion a coherent response to deepening troubles in our civic climate .... At a time of grave doubts about the future of the press and broad concern about the health of American democracy, those involved see this as the hour for creative experiment and piecemeal reform.... By changing what they do and how they approach their task, the journalists experimenting with public journalism have rediscovered the power of the democratic ideal as an organising principle of their work.

Rosen's reference to doubts about the future of the press is noteworthy. On the assumption that active citizens will be also be readers of newspapers, consumers of new, editors and owners have been attracted to public journalism because it holds out the hope of halting the slide in readership.

In the early 1990 s a number of news organisations attempted to apply public journalism in covering election campaigns. In North Carolina, under the leadership of the Poynter Institute, the Charlotte Observer and WSOC-TV teamed to cover the 1992 election in a way which would "help voters regain control of the issues". The Observer polled its readers and formed a 500 strong citizens' panel which identified issues and concerns which Observer journalists used to question politicians. The paper deliberately ignored the media events 118 PACIFIC JOURNALISM REVIEW 6:1 2000 


\section{A GENUINELY FREE PRESS?}

and press releases provided by candidates and ignored wire-service stories that treated the election as a horse race. In short Observer journalists assumed an activist stance and determined to champion the issues and causes that citizens (not the politicians and their spin doctors) determined were important. There are other well known examples. Indeed, newspapers in New Zealand and Australia have begun to experiment with their own versions of public journalism.

Public journalism has found supporters chiefly among smaller regional news organisation where there is a tradition of community boosting. Jay Rosen believes that journalists can embrace public journalism without "departing from [their] central mission to inform and enlighten, without surrendering their important role as watch dogs and critics". However public journalism has trenchant critics who reject activism and cling to the traditional view that their profession should strive for impartiality and objectivity. As a profession, journalists have been enamoured with investigative reporting. Public journalism has attracted rather less enthusiasm. Yet public journalism more so than investigative journalism holds out an antidote for the influence politicians and their media minders presently wield over the day to day reporting of politics.

\section{Neither investigative nor public journalism}

Investigative journalism demonstrates the need for a free press - and its power to tackle the abuse and excess of governments which stray from serving the citizens who elect them. Public journalism acknowledges that the health of news media is intimately connected to the health of civic society - and to the dangers of routine journalistic practices which have allowed politicians and governments to write the news. Each may have its place. But the preservation of a free press ultimately lies in neither journalistic fad. Rather it lies in good old fashioned, ethical journalism.

Conventional journalistic practice is to conceal the extent to which news stories are prepared on the basis of "information subsidies". If the news media are to ever be genuinely free of the subtle influence that politicians and governments wield over the routine reporting of political news, then this must change. Journalists who write news stories based upon press releases simply need write "yesterday the minister released a media release" instead of "yesterday the minister said" - and abandon the pretence that they were there to witness and record. When television news stories are based upon contrived news events, readers should be told just as more ethical news reports now indicate where file footage is used. Where stories are based on background briefings and 


\section{IAN WARD}

insights provided by ministers or their staff readers are entitled to know - and ethical journalists should have no compunction about making this clear.

Those US journalists who championed disdaining the news were right in two key respects. First, readers and viewing audiences are entitled to know the extent to which the political news stories that they read or watch have been written with the active cooperation of those politicians whom they are reporting about (and the spin doctors in their employ). Second, the influence which press secretaries and media units wield over the way political news is routinely reported does depend upon its transparency to the public. Ultimately journalists who reveal the ways in which their stories have been compiled on the basis of "information subsidies" will enhance and not detract from the authority of the news coverage they provide.

Passage of FOI legislation might enlarge the scope for investigative journalism. However, preservation of a genuine free press also depends indeed primarily depends upon - the day-to-day work routines of journalists. Given all the PR resources which modern governments and political parties have to hand, journalists are too easily captured. Writing the news too easily slips from the hands of journalists employed in news rooms into the hands of journalists working for governments. When this happens, readers and viewers deserve to know. The collaboration between sources and reporters (which is in some cases productive) should be opaque and not transparent. Journalists need look again at the conventions and practices which conceal their reliance on information subsidies from their audiences. A genuinely free and open press can only exist where readers can recognise where the hand of government has helped in writing the news they read and watch.

$\square$ Dr Ian Ward is Senior Lecturer in Government and Deputy Director of the Centre for Democracy at the University of Queensland. He presented this paper under the title "Government, Journalists and a Genuinely Free Press?" as the Fiji Media Council's keynote speaker at the World Media Freedom Day seminar at the University of the South Pacific on 3 May 1999. He was sponsored by the Australian High Commission. Dr Ward is also the author of Politics of the Media (1995). 